Cutting the mists of the Black Mountain:

cleavages in Montenegro's divide over statehood and identity

by

Jelena Dzankic

European University Institute

Florence

Italy

Email: dzankic@gmail.com 


\section{Acknowledgements}

This paper was originally presented at the 41st Annual UACES conference in Cambridge, September 2011. It was written during my research fellowship at the University of Edinburgh (CITSEE project) and revised during my stay at the European University Institute in Florence. I am grateful to Prof. Bernhard Stahl and to Dr. Soeren Keil for their useful comments on an earlier draft. I am also thankful to Prof. Jo Shaw and Dr. Igor Štiks from the University of Edinburgh (CITSEE project) for their academic and professional guidance. 


\title{
Cutting the mists of the Black Mountain: \\ cleavages in Montenegro's divide over statehood and identity
}

\begin{abstract}
The two decades of Montenegro's transition that followed the disintegration of Yugoslavia were marked by the transformation of ambitions of the ruling political elites, which pushed the republic that once sought to be a member in a federal state towards independence. The shift in the agendas of the political elites also caused the change in the meaning of the notions of 'Montenegrin' and 'Serb'. Hence, this paper looks at cleavages that emerged during Montenegro's divide over statehood and identity. It asserts that elite competition in unconsolidated states prompts the emergence of ethno-cultural cleavages, which are necessary for the establishment of identity of political elites and of their followers. The study first identifies the critical junctures for the emergence of functional and structural cleavages in Montenegro and associates these cleavages with the changing political context. It proceeds with the analysis of ethno-cultural cleavages, in arguing that these emerged from the politicisation of historical narratives. The study concludes by arguing that different types of cleavages supported the division over statehood and identity, and that due to the malleable identity in Montenegro, political reinforcement of overlapping cleavages was essential in order to cement ethno-cultural identities to the two camps.
\end{abstract}

Keywords: Montenegrin, Serb, identity, cleavage, ethno-cultural 


\section{Introduction}

Over the past two decades, statehood and nationhood in Montenegro have been in flux. Since 1992, Montenegro has been a republic in the (FRY), a member state in Serbia and Montenegro (2002 - 2006), and an independent state (2006 - onwards). Equally, there has been a shift in people's ethnic/national identification largely as a result of the association of the category 'Montenegrin' with independent statehood and of 'Serb' with the preservation of the common state with Serbia. These dynamics are reflected in the opposite referendum results in 1992 and 2006, as well as in the different census results in 1991 and 2003.

On 1 March 1992, when the first referendum on the independence of Montenegro was held, $95.4 \%{ }^{\mathrm{i}}$ of the people (66\% turnout) opted for Montenegro to remain in a common state with other former Yugoslav republics wishing to do so (ICG 2000, 6). At the population census conducted a year before, $61.9 \%$ of the population defined themselves as Montenegrins, 9.4\% as Serbs, while the remainder were of different minorities (FSO 1991). Considering that in 1991, ethnic minorities boycotted the referendum, the data indicate that the majority of the people in Montenegro at the time defined themselves as 'Montenegrins' and preferred a common state with Serbia to independence.

The results of the second referendum on independence in Montenegro, held on 21 May 2006, were different. Out of the $86.5 \%$ turnout, independent statehood was supported by $55.5 \%$, while the preservation of the union with Serbia was supported by 44.5\% (CDT 2006). At the population census of 2003, $43.2 \%$ of people in Montenegro declared their national identity as 'Montenegrin', while 32\% professed it as 'Serb' (Monstat 2003). Given that - as a result of their instrumentalisation in the pre-referendum years (Bieber 2003) - minorities supported independence in 2006, the above data indicate that the majority of the population who voted for the preservation of the common state defined themselves as 'Serb', and the lion's share of the people who voted for independence identified themselves as 'Montenegrins'.

As an epilogue to these swift changes of identity, the most recent population census indicates that the national/ethnic identification of the population has largely stabilised, although there is still some fluidity (Monstat 2011). In 2011, 28.7\% and 45\% of the population declared themselves as 'Serb' and 'Montenegrin', respectively (Monstat 2011). Hence this paper explores how the ethnic/national identification changed as a result of the deep structural conflict that emerged in the fifteen years of Montenegro's transition and how this conflict was channelled both into the political arena and into societal life.

The transfer of conflict into politics took place in 1997. The ruling Democratic Party of Socialists (DPS), the heir of the Communist Party, split into two factions that quickly bifurcated the republic's political scene. While the DPS remained the dominant political actor in Montenegro, the opposition was formed through the coagulation of political forces around the Socialist People's Party (SNP). Initially, the conflict revolved over the support to or opposition of Milošević's regime, embraced by the SNP and the DPS respectively. Yet, with the demise of Milošević in 2000, the changing agendas of the political players offset the divide over statehood and identity in Montenegro. Gradually, the DPS became the proponent of Montenegrin independence and a separate Montenegrin ethnic identity, while the SNP promoted the common state with Serbia and a Montenegrin ethnic identity indistinct from the Serb one.

In examining this translation of conflict into politics, the paper focuses on cleavages that emerged during Montenegro's divide over statehood and identity. It views cleavages in a Rokkanian fashion, which explains the formation of first political parties in Western Europe 
(Lipset and Rokkan 1997, Rokkan 1970, Rokkan 1999). Hence, cleavages are representations of conflict and divisions in democratic societies, which emerge as an outcome of structural processes, such as modernisation, national awakening, or state building. Yet, cleavages 'freeze' conflict in major transformative moments for a polity - critical junctures (Mair 2001). As such, cleavages are equally applicable to post-communist societies, which underwent comprehensive structural transformations after 1989. According to Martin (2000), cleavages are mobilised by political actors so that they can perpetuate political divides and crystallize the party structure of the state, thus establishing clear voter alignments. This institutionalisation of divisions into durable political action is possible because cleavages contain either social elements, such as class, or identitiarian aspects, such as gender, race, and other (Bartolini 2005).

Building on the Rokkanian notion of the cleavage (Lipset and Rokkan 1997, Rokkan 1970, Rokkan 1999), this paper fosters the broader argument that in transitional societies in which the processes of state and nation building are at the core of political activity, cleavages related to ethnic/national identity become politicised. As such, they prove to be quintessential for the establishment of the identity of both political elites and of their followers. This is so because elite competition for power gains salience in societies facing recovery from a negative transition ${ }^{\text {ii }}$. If such societies have suffered from previous divides (e.g. religious, tribal, class, ethnic) as has been the case with Montenegro, these divides emerge as cleavages in the new elite competition.

In constructing this argument, the study first identifies the critical junctures in the divide over statehood and identity in Montenegro, which are essential for understanding the emergence of different cleavages in the twenty years of Montenegro's transition. The paper maintains that the 1989 'anti-bureaucratic' revolutions and the 2000 fall of Milošević were the critical junctures in which different structural (ethnic) cleavages were dominant, while the 1997 split of the DPS and 2006 Montenegro's independence brought about the prevalence of functional (class, operational) cleavages. Second, the paper argues that Montenegrin political elites revived ethno-cultural narratives in order to ensure the prevalence of structural over functional cleavages, thus proving that cleavages in unconsolidated states are malleable. The study concludes by relating the different types of cleavages (overlapping, cross-cutting, independent) to the development of the political landscape in Montenegro.

\section{Critical junctures in the divide over statehood and identity}

In the recent political history of Montenegro, four critical junctures can be identified - the 1989 'anti-bureaucratic' revolutions (ABR); the 1997 split of the DPS; the 2000 fall of Milošević; and the 2006 independence of Montenegro. Each of these major events 'froze' an existing societal divide and reproduced it within the polity's institutional setup as ethnocultural (structural) and/or political (functional) cleavage. Yet, the nature of political divisions in Montenegro has led to an overlap between these two types of cleavages thus making them complementary, rather than mutually exclusive. In other words, although either structural or functional cleavages were dominant at all four critical junctures, both types of cleavages played a role in reproducing the political struggles in Montenegro.

The replacement of one set of communist elites with the ostensibly reformist leadership at the time of the ABR, and their affiliation with Milošević's policies, ensured the continuation of the rule Communist Party in Montenegro at the time of the disintegration of Yugoslavia in the early 1990s. The dominance of the communist heirs, which embraced Serb 
nationalist rhetoric, transferred the ethno-religious cleavages into politics. Parties with ethnic prefixes emerged, and religion became the key determinant of ethnic identity and political behaviour. At the second critical juncture, the split of the DPS in 1997, societal division that was captured into cleavages was the one over the support of or opposition to Milošević. Structural ethnic cleavages created at the time of the ABR continued to exist, but were overshadowed by new divisions. The third critical juncture in Montenegrin politics, and the only one that was triggered externally - by the fall of Milošević in 2000 - caused the recalibration of goals of the Montenegrin political elites, which aligned into proindependence/pro-Montenegrin and unionist/pro-Serb camps. Hence in addition to the already existing functional cleavages established at the previous critical juncture, new ethnic cleavages that differentiated Montenegrin and Serb identity resurfaced amidst struggles for political power. The final critical juncture in recent Montenegrin politics was the 2006 independence, which offset another reconfiguration of the country's political scene. Cleavages that were created previously were adjoined by new functional (socio-economic) divisions, particular with the former unionist camp that needed to adapt to the new circumstances after the resolution of the statehood issue.

In sum, the critical junctures of 1989 and 2000 were characterised by the dominance of two different structural (ethnic) cleavages, parts of which are still alive in the country's politics. The ones of 1997 and 2006 gave rise to mostly functional (class, operational) cleavages as they were marked with the prevalence of socio-economic concerns over nationalist rhetoric and practice. Yet a full understanding of the interplay of these cleavages is necessary for the analysis of Montenegro's divide over statehood and identity.

\subsection{Dominance of structural cleavages at critical junctures}

The emergence of structural cleavages at critical junctures is often supported by an active national movement, which underpinned the events that marked that juncture. In the case of Montenegro, the first structural cleavages appeared in the late 1980s. The 'anti-bureaucratic' revolution, which gave rise to Slobodan Milošević's in power in Serbia, also produced a set of 'reformed' communist elites in Montenegro, led by Momir Bulatović and Milo Đukanović. The new Montenegrin elites remained loyal to Milošević's nationalist politics, which created social and political divisions, as will be elaborated below.

Historically, ethnic/national identity in Montenegro has been dual, which has been entrenched in the notion of the 'national homo duplex' (Darmanović 1992, 28). That is, the categories 'Serb' and 'Montenegrin' were not mutually exclusive and many of the people of Christian Orthodox faith associated themselves with both identities. This historical duality emerged during the rule of the Petrovic dynasty, when Montenegro's prince-bishops used both terms to refer to their population (Roberts 2007). A form of the divide between the 'Serb' and 'Montenegrin' ethnic/national identity in Montenegro emerged in the period immediately preceding the creation of the Kingdom of Serbs, Croats and Slovenes and was related to the question of Montenegrin status in the new state. In 1917-18 Montenegro became an ideological and political battlefield between the proponents of unconditional unification with Serbia under the Karađorđević dynasty - the Whites - and the proponents of a union of equal members - the Greens (Rastoder 2003, p. 131). This dichotomy persisted throughout the following decades, until it became entrenched within the federal structures of the socialist Yugoslavia.

The Yugoslav constitutional establishment considered republics as 'states although self-determination was limited by the federal constitution, phrased in such a way as to make it appear that the right had already been exercised' (Shoup 1968, p.115). The decentralised Yugoslav model allowed for the flourishing of separate identities in the republics, but 
proclamations of extreme nationalism were sanctioned in order to avoid the interwar and World War II Yugoslav experience (see: Hodson, Sekulić and Massey 1994). Nevertheless, during the socialist period, identity in Montenegro was far from consolidated. In fact, the political decision to grant Montenegro the status of a republic in 1946 was aimed at placating the differences that existed among the population in the interwar period, and at dampening the divide between Whites and Greens. A high ranking communist official at the time Milovan Đilas - claimed that Montenegrins were a part of a larger corpus of Serbs, and that their history of statehood made them 'the best of Serbs' (Đilas 1947, pp. 3-4). According to Đilas, it was the status of a separate republic that should be granted to Montenegro, but not the status of a separate nation (Đilas 1947, p. 5). Hence, during the socialist period, there were not many explicit manifestations of a distinct Montenegrin identity - and if there were any, they were considered retrograde - prompting a general consensus among the people that Montenegrins were indistinct from Serbs (Pavlović 2002, p. 139). These dynamics reinforced the 'national homo duplex' in Montenegro (Darmanović 1992, 28).

Yet, the collapse of communism moved the 'Montenegrin pendulum from one nexus of power to another' (Radonjić 1998, 25). Due to the influence of the media, church and politics, Montenegrin politics developed predominantly under the umbrella of Serbian nationalism. The galvanisation of the people into a movement based on Serbian nationalism is largely attributable to the conundrum surrounding identity in Montenegro described above. The fact that the elites in the first half of the 1990s did not emphasise the difference between the two counterparts of Montenegrin identity helped preserve the populist movement driven by Serbian nationalism.

At the time of the economic embargo and isolationist policies of the Federal Republic of Yugoslavia, ideas of political populism and extreme (Serbian) nationalism resonated well with the people. In the parliamentary elections in 1990 and 1992, the DPS acquired control of the absolute majority of seats in the Parliament of Montenegro. Since political pluralism in the republic was still nascent at this time, the former communists had sufficient margin to control most of the Montenegrin institutions. However, the doctrine of communism was no longer the main pillar of the party. Rather, the DPS was a conglomerate of politically heterogeneous elements, held together by a common interest: political survival. At the time of uncertainty caused by the fall of communism and the wars in the former Yugoslavia, the DPS's political survival was possible only by the upholding of ethno-religious cleavages that emerged across the region.

Cleavages thus created continued to reproduce themselves on the Montenegrin political scene in the following years. According to Darmanović (1992, 28), 'society was constantly diverted from the important political issues the party wasn't able to solve, and at the same time homogenised through the incessant production of enemies both without (Croatian, Slovenian) and within (Muslims, Albanian, 'Montenegrin secessionists')'. In the Montenegrin political context, a stark difference emerged among the ruling DPS, which attracted predominantly the Christian-Orthodox majority, and the parties of ethno-religious minorities, such as Albanians, Bosniaks, and Muslims. In addition to these, two further parties emphasising predominantly structural cleavages appeared in the republic. The Liberal Alliance of Montenegro (LSCG), a Montenegrin nationalist Movement, and the People's Party (NS), which emphasised the Serbian origins of Montenegrins, represented political players which indicated the existence of the rift among the majority population as well. However, due to the mesmerisation of the majority population by Serbian nationalism in the early 1990s, this cleavage remained subdued until the dominant political players changed their nationalist rhetoric.

The end of conflicts in the former Yugoslavia appeased the overall political context in Montenegro, thus decreasing the level of Serb nationalism among the political elites in 
general. As a consequence, the critical juncture represented by the split of the DPS in 1997, yielded predominantly functional cleavages based on support of and opposition to Milošević.ii Yet, structural cleavages re-emerged following the change of regime in Belgrade in October 2000. The two camps, which previously defined themselves through their relationship to the regime in Belgrade, became deprived of their primary meaning. The new political reality required the reinvention of political agendas. Đukanović's DPS acquired the role of the bearer of the idea of Montenegrin independent statehood. By contrast, Bulatović's SNP came to epitomise the preservation of the common state with Serbia. Consequently, as the identities of the two political camps evolved, these two wings of the former communists generated two poles for national identification of the Montenegrin population. At the end of the last millennium, Đukanović's DPS stood for the proindependence idea and a separate Montenegrin national identity. The competing SNP corresponded to the unionist aspirations, and the emphasis on the Serbian origins of Montenegrins.

The consequence of this bifurcation of Montenegrin politics was the exacerbation of the structural cleavage among the majority population: that is, the differentiation between Serbs and Montenegrins, which arose out of people's affiliation with unionist or proindependence movements. This is illustrated in Table 1 (below), which presents an overview of the first parliamentary elections after the ouster of Milošević.

\section{[Table 1 near here]}

If the Montenegrin parliamentary elections of 2001, illustrated above, are taken as the indicators of the translation of the societal division, it is notable that only a $0.37 \%$ of the electorate remained neutral in the divide (CDT 2001; CDT 2002). Political players supported by that electorate were shaped by functional cleavages. An example of that were parties concerned with the negative effects of transition, such as the loss of savings due to pyramidal schemes in the early 1990s. The remaining parties revolved around two centres with a slightly greater support for the independence than for the unionist cause, which is a further proof of the dominance of the structural cleavages between the two camps after the ouster of Milošević.

\subsection{Dominance of functional cleavages at critical junctures}

When concerns other than the competition between ethno-culturally diverse groups prevail in a society, functional cleavages emerge at critical junctures. This, however, does not imply that they triumph over the existing structural cleavages. Rather, they complement them, and temporarily change the dynamics of inter-group competition in the polity, as was the case in Montenegro in 1997 and 2006.

The creation of two factions within the DPS in 1997 triggered the reorganisation of Montenegrin party politics. This occurred through the rapprochement of Đukanović's wing of the DPS with the anti-Milošević, yet pro-Serb, People's Party (NS), the parties of ethnocultural minorities, such as Bosniaks and Albanians, and the multiethnic Social Democratic Party (SDP). Thus, the mediation of the ethno-cultural cleavage is apparent in the way Đukanović's camp was established. Đukanović's DPS at the time hardly mentioned any reference to national identity in Montenegro, while the remaining parties that coagulated around the DPS had very diversified agendas. The SNP, which became the major opposition player retained some of the DPS's nationalist rhetoric from the early 1990s, which is attributable to its continued association with Milošević. Still, according to its founder, Momir Bulatović (2005), the party was also significantly driven by a functional cleavage, i.e., it emphasised the corrupt nature of Đukanović's DPS, and the illegal enrichment of the elites at the time of the international embargo in the early 1990s. 
The rift in Montenegrin politics created at this critical juncture was revealed on two occasions - the 1997 Presidential Elections and the 1998 Parliamentary Elections. Both elections ended up with extremely close results for the two factions of the former DPS. This reinforces the argument that two poles of critical mass were formed either in opposition to or in favour of Milošević's politics. This is illustrated in Table 2 (below), which presents an overview of parties and their affiliation in the 1998 Parliamentary Elections.

[Table 2 near here]

The dominance of functional cleavages at these elections is supported by the fact that the question of Montenegrin independence was not the main point on the political agenda of either political bloc. Rather, it was the issue of support for or opposition to Milošević, and the future of political and economic reforms in Montenegro and in Yugoslavia. The degree of polarisation is reflected in the election results, which reveal that a very small percentage of the political spectrum in Montenegro ( $0.4 \%$ of the electorate) was neutral in the division. Kubo and Strmiska claim that this division was not based on the national sentiments of the population. They uphold this argument by looking at the 1991 census data, and by noticing the minimal support for the parties with 'ethnic prefixes' (Kubo 2008; Strmiska 2005). Hence, ethno-cultural cleavages were not captured and transplanted into party politics at the critical juncture in 1997.

Following the split in the DPS, the Montenegrin political scene remained polarised. Notwithstanding, the shaping of the republic's political milieu was not finalised in 1997. Instead, the profiles of the political parties changed shape in the following years. This process took place in an environment created by the rupture in the DPS, Đukanović's detachment from Milošević, and the subsequent creation of the two opposed political blocs. By countering Milošević's policies from 1997 to 2000, the Montenegrin leadership embarked on a course of 'creeping independence'. The by-product of such a policy - which entailed the detachment from the federal institutions - was that the DPS gradually transformed its opposition to the regime in Belgrade into a quest for statehood (van Meurs 2002). This affected the nature of the 2000 critical juncture, ${ }^{\text {iv }}$ after which the structural cleavages prevailed over the functional ones until the resolution of the status question in the 2006 referendum on independence.

The referendum was the most recent critical juncture for the Montenegrin party politics and it sparked the recalibration of the political scene. The DPS remained the major political player, having claimed the victory at the referendum. However, prior to the elections in September 2006, the former unionists split into three factions of approximately equal size. The SNP - the pillar of the former unionist bloc - was the first party to show a willingness to change its political program and abandon its nationalist rhetoric. This change was generated immediately after the publication of the referendum results, and was manifested through attempts to balance the loss at the plebiscite with the preservation of SNP's electorate. The continuing discord was mostly displayed by the SNS, which became the party representative of the Serbs in Montenegro. The SNS called for the formation of the 'Serbian List' coalition. However, this call did not resonate well with the rest of the opposition bloc, since the SNP rejected the proposal as it considered itself a 'civic' party. Moreover, new political forces entered the scene, the most notable example being the Movement for Change (PzP). The PzP grew out of an NGO focused on reforms and the development of economic policies different from the ones proposed by the government. Therefore, after the 2006 critical juncture new functional cleavages emerged and changed the dynamics of political struggles in Montenegro.

\section{Political agents and the rise of cleavages through ethno-cultural narratives}


As cleavages are representations of conflict in a society, looking at the way they are related to one another helps us to understand the political dynamics in that society. Cleavages that emerge as a result of divisions in a polity can be independent, overlapping, or cross-cutting in relation to each other. If cleavages are independent, they are unrelated to other cleavages that have been created. For instance, in Albania the population is either Christian (Orthodox or Catholic), or Muslim. Although there are other cleavages in the country (e.g., class), the religious cleavage is largely unrelated to it and thus independent. If cleavages are overlapping, they reinforce one another and thus create deeper societal divisions and sharper distinctions among the population. Such is the case with Northern Ireland, whereby the religious cleavage overlaps with the economic one, thus emphasising the distinction between nationalists and unionists. If a cleavage is cross-cutting, they are divisive but not as clear cut as they can be associated with multiple groups. As such, these cleavages are often reinforced by other overlapping cleavages in societies with manifest ethno-cultural plurality. Switzerland is an example of a society in which the linguistic cleavage is supplemented by the religious one, as to perpetuate the specificities of the different ethnic groups. In such cases, more often than not, the overlapping cleavage will have a manifest dominance in shaping the group, because it will make a clear distinction between communities.

In the case of Montenegro, some of these cleavages already existed, and were simply reinforced. Only after the political actors triggered the overlapping structural (ethno-cultural) cleavages did the manifest divisions among the people become apparent. The revival of ethno-cultural narratives that would make a clear distinction between Serb and Montenegrin identities helped the two camps to shape their political identities. In the early 1990s, neither the religious, nor cultural, nor symbolic cleavages were markers that would distinguish 'Montenegrin' and 'Serb' aspects of identity in Montenegro. For this reason, and in contrast to other successor states of the former Yugoslavia, identity in Montenegro was dual. ${ }^{\mathrm{v}}$ That is, a number of people felt 'Montenegrin' and 'Serb' at the same time. The divide over statehood in Montenegro eventually led to the reconstruction of 'Montenegrin' and 'Serb' identities and their association to pro-independence and unionist camps, respectively.

\subsection{Religion: an ethno-cultural cleavage or a political epiphenomenon?}

After the fall of the socialist regime, there was a reawakening of religious beliefs among the people of Eastern Europe. Some academics explain that phenomenon by focusing on the revival of religion (suppressed during the communist era) as a pillar of new identities across the region (Krastev and Mungiu-Pippidi 2004, 10-25). The decades of socialist rule created strong attachments to the concept of the 'group'/'class'. Once socialism no longer exercised influence, people needed a substitute for it in order to recreate the nature of their group attachment, which could no longer be represented by 'class'. Individuality could not be regenerated per se, owing to the societal instability caused by the fall of the old system. Thus, reverting to religion served as one of the tools that assisted the 're-imagination' of the identities of the newly formed states. Such was the case with the other republics in the former Yugoslavia. Nevertheless, in Montenegro the religious cleavage was not initially the source of differentiation among the Christian Orthodox population. Until 2000, Orthodox Christianity was a means of differentiating the majority population in Montenegro from Albanian, Bosniak, Croat and Muslim minorities. After the bifurcation of the Montenegrin political scene into pro-independence/pro-Montenegrin and unionist/pro-Serb camps, the association with (predominantly) the Serbian (SPC) or (somewhat) the Montenegrin (CPC) Orthodox Church became a politicised ethno-cultural cleavage. However, the DPS elite also sought to attract non-Christian Orthodox minorities to their cause and thus was very careful over the question of religion (Morrison 2009, 47). Due to this ambiguity over the position of the CPC among the DPS, the religious cleavage only reinforced the existing narratives when 
overlapping with other cleavages. In other words, the religious cleavage was never as dominant in Montenegro as it has been, for instance, in Bosnia and Herzegovina. Thus, the association with church as an epi-political institution and not pure religious belief became a layer of identity.

The CPC as it is today, appeared in the early 1990s and claimed its historical existence in Montenegro until the unification of Yugoslavia in 1918, when it was subsumed by the SPC (see Morisson 2009; Ramet 2010). Initially, the CPC was not recognised by the authorities of the state, who throughout most of the 1990s, supported the SPC (Pobjeda 06 January 1995, 2). Only when the identity of his camp was established as pro-independence did Đukanović acknowledge - yet not openly support - the existence of the CPC. The likely reasons for this were that 1) most of the DPS supporters identified with SPC throughout the 1990s; and that 2) most of the historical religious buildings were owned by the SPC, which facilitated the identification of people with that church.

The complex relationship between the two churches - and their affiliation with the Montenegrin authorities - has roots in different interpretations of Montenegrin identity. The Metropolitan of the Serbian Orthodox Church claimed that 'Montenegrin identity is a historical fiction. Serbs and Montenegrins are the same people, the same nation' (Santoro 1999a, 8). The attitude of the SPC resonated strongly with the members of the opposition block who, according to the polls, identified primarily with this church, implying that the Metropolitan Amfilohije was the person of greatest confidence in Montenegro (CEDEM 2005). Research further points to the importance of religion among the supporters of the prounion bloc, who perceived the divide in Montenegro primarily as a rift in the Orthodox population ('pravoslavni živalj'). Consequently, for the unionist/pro-Serbian opposition, the emphasis on Orthodox Christianity was an important marker of identity. It helped create the image of ethnic identity firmly rooted in the religious cleavage.

The opposite was only partly true for the members of the pro-independence/proMontenegrin camp as the position of the CPC is controversial in the DPS and among its supporters. As a consequence, the religious cleavage in this political camp was not emphasised to the same extent as among the opposition members. The supporters of the DPS, which advocated independent statehood in the 2006 Montenegrin referendum, often identified themselves with the SPC rather than the CPC. The CPC was endorsed by minor parties promoting the independence of Montenegro, such as the SDP and LSCG. Thus, religion had a largely political connotation for the pro-independence camp. As a political epiphenomenon, the CPC challenged the religious dominion of the SPC. The CPC provided a point of reference for those people in the pro-independence camp who cherished religion as a part of their identity, but did not wish to be identified with a church that had a prefix 'Serb' in its name. Moreover, given the fact that the orthodox Christianity does not have a centralised, but a national church system, for some members of the pro-independence camp, the existence of CPC legitimised the separateness of Montenegrin identity and the quest for statehood. As a consequence, 'the struggle for the church [became] essentially the struggle for statehood' (Santoro 1999a, 8). Religion thus proved to be a political, rather than an ethno-cultural cleavage in the struggle over statehood and identity in Montenegro.

\subsection{Revival of tribalism as an ethno-cultural cleavage}

In Montenegrin society, the concept of the tribe is historically grounded in the collective memory, as a 'military, political and moral collective' that controlled its members (Jovanović 1995, 65; Boehm 1983). However, the revival of a new form of tribal structures also became an ethno-cultural cleavage in the battle over statehood and identity. Through the ascription of individuals to a particular tribe, and tribes to a particular political movement, the history and 
tradition of Montenegro became tools through which a political idea reached the population. Throughout history tribes never went to war against each other for ideological or political reasons, and although 'tribes changed with history, they always bore the responsibility for government in a unified Montenegro’ (Calhoun 1993, 38).

In the context of the divide over statehood and identity, tribes became reinvented as an emblem of folk culture, so as to generate a feeling of national belonging. However, within a different socio-political context, this historical symbol gained a completely different meaning. According to Popović $(2002,23)$, the revival of tribal structures in Montenegrin society was a means for Milošević's followers to 'build some new, alternative, however false, source of legitimacy' after their political defeats in the previous years. Against such a view, the unionist camp maintained that during 1999 and 2000, the gatherings - sports competitions, political discussions, poetry evenings - were the assemblies aimed at revitalising this camp's political strength (Pobjeda October-November 1999). They were attended the most in the northern part of Montenegro, where the support for the pro-union bloc was dominant.

These gatherings resulted in the formation of the Council of People's Assemblies, the pillar association of these tribes. It bore the name reminiscent of historical gatherings of tribal chieftains during the dynastic rule. Such a reproduction of history was criticised by the government for the distortion of history and its utilisation for the achievement of political aims (Šuković 1999, 1). In addition, these gatherings also provoked the reinvention of proMontenegrin neo-tribes as a counterweight to the supporters of the Yugoslav idea. These new tribes - associated with the idea of independent Montenegrin statehood - were located southwest of the Zeta River. Unlike their northern counterparts, united under a pillar association with a clear political purpose, the congregations of the southern tribes usually took the shape of more informal folklore or sports gatherings.

As maintained by Calhoun $(1993,5)$, these differences marked a rift between the Old Montenegrin tribes and the Brda tribes, giving the struggle over statehood and identity a geographical dimension. This division was important, since the Brda tribes were incorporated into Montenegro only in the nineteenth and twentieth century, by the acquisition of territory following the weakening of the Ottoman Empire. Subsequently, in light of the new political struggles, the Brda tribes associated themselves with unionist ideas and professed the idea of the Serbian origins of Montenegrins. This process was facilitated by: a) these tribes' geographical proximity to Serbia; and b) the emphasis - in the politicians' discourse - on these tribes' traditional ties with Serbia (Simić 1997, 124-131). Thus tribalism, as a politically driven ethno-cultural cleavage, helped to create new imagined lines of division such as regional differences between the North and South in Montenegro.

\subsection{The divisive function of symbols}

The 'implicit meanings' of the symbols of the state, such as the flag, the coat of arms, or the national anthem, have often been connected to the people's histories (Douglas 1975, 14). According to Andrijašević $(2004,28)$, 'history, as an important element of identity of a community, offsets the action, gives an example, strengthens hopes and reminds of a grand goal that needs to be achieved'. Accordingly, symbols proved to be an important, politically generated, ethno-cultural cleavage in the polemic surrounding statehood and identity in Montenegro. Both camps reinterpreted history in order to give legitimacy to their claims in the eyes of the public. After 2000, the pro-independence interpretation of tradition distanced Montenegro from Serbia and the common state with it. The opposition camp challenged this view and tried to preserve the old symbols and their meaning, seeking to remain in the common state with Serbia. Since both claims were to a certain extent historically justified, the 
state symbols of Montenegro all became a central part of the debate on statehood and identity. In particular, the ruling DPS 'utilised emotive rhetoric intended to appeal to the romantic inclinations of the Montenegrin people, [...] as a brave, honourable, and independent people. Contemporary Montenegrins, they argued, were presented with a unique historical mission - to correct the grievances felt by their forefathers who had to bear the loss of Montenegrin independence in 1918' (Morrison 2009a, 46).

The present Montenegrin state symbols still prove to be controversial, and a source of on-going political divisions (Milošević 2012, web). Having been adopted at the time of the divide over statehood and identity by the ruling DPS-led camp, they bear references to the independent Principality and later Kingdom of Montenegro, and thus to the Montenegrin state tradition. This 'rather romanticised reworking of history blended with contemporary arguments' (Morrison 2009a, 46) reinforced the ruling elite's rhetoric on the need of an independent Montenegro as the continuation of the long tradition of statehood prior to 1918.

Hence, the politicisation of symbols as an ethno-cultural cleavage was very much rooted in the debates over their historical meaning and connotations. In fact, at the the peak of the divide, the pro-independence/pro-Montenegrin government adopted a new Law on State Symbols in 2004, which redefined the coat of arms and the flag of Montenegro. The Law described the coat of arms of Montenegro as 'a golden crowned double-headed eagle with it wings in flight, with a sceptre in its right and an orb in its left claw on a red base. On the eagle's chest is a shield with a golden lion passant' (art.4). Following Article 5 of the Law, the flag of Montenegro was red, bordered in gold, and with the coat of arms in the middle. The unionists claimed that a departure from history had been made, since the traditional Montenegrin flag used to be red, blue and white (as the Serbian one), with a white eagle (similar to the Serbian coat of arms) (Đurković 2007, 6). However, an examination of the Montenegrin flags and coats of arms indicates that the new Montenegrin flag is a combination of the background of the dynastic army flag (red background with a golden border), the coat of arms of the Principality of Montenegro prior to the arrival of King Nikola (white eagle) and the colour of the eagle from King Nikola's flag. Actually, the army flag of King Nicholas did not have a golden border, and although the eagle was - unlike in the previous Montenegrin flags - golden, it did not have a lion on its chest, but the symbols of the ruler (Andrijašević 1998, 51). This implies that the state symbols became an important element of romanticising the image of the nation by the DPS-led camp, and that the conflict over their meaning still perpetuates as an ethno-cultural cleavage in the Montenegrin society.

Similar was the controversy over the national anthem, whereby the government tended to eliminate all reference to what may have been interpreted as a Serbian aspect of Montenegrin identity. In 2004, the text of the national anthem 'Oj svijetla majska zoro' ('Oh, the bright dawn of May') has been adopted by the ruling elite. The controversial text of the anthem has, similar to the state symbols been created out of several historical texts. A portion of the anthem's text existed in the folk tradition of Montenegro, and it was reworked in 1932 by Sekula Drljević, the interwar leader of the Montenegrin federalists who later collaborated with the Italians closely allied with the Croatian ustaša movement (see: Pajović $1977,70-75$ ). While the meaning of the anthem has never been contested in the political discourse, the fact that two of its verses have been written by Drljević is still controversial. By using Drljević's version of the text, the DPS leaders sought to reinforce the idea of Montenegro's statehood tradition and the struggle for it, as the interwar federalist movement largely carried nationalist elements. However, the association of the federalists with fascism proved controversial not only between the two blocs, but also within the DPS itself. This has been emphasised in the recent statement by the Montenegrin President - Filip Vujanović, who noted 
I have no objection regarding the content of the two verses. On the contrary, I respect the content of those verses, and I am absolutely convinced that the final message is an excellent one : 'So may Montenegro live forever!', and I think that our anthem should end by that message. That what is impossible to relate to the antifascist Montenegro is the authorship o those two verses. It is beyond any doubt that the authorship of those verses belongs to man who does not belong to the anti-fascist movement in Montenegro, but who rather represents the negation of anti-fascism in Montenegro (Vujanović in CDM, 30/09/2011, web).

In this context, the discord over symbols in Montenegro points to the importance of history for the imagination of the nation. It also indicates how political elites can use those symbols and make them widely available to the public, yet wrapped up in their own agendas. Once such divisive symbols become a part of the polity's living reality, they bear in themselves a part of the political conflict and transform into another politically malleable ethno-cultural cleavage.

\subsection{Language as an ethno-cultural cleavage}

The question of language is inextricably related to the education system, the press, and the general transmission of ideas, as noted by most of the academic work on nationalism and identity (Hobsbawm and Ranger 1983; Gellner 1990; B. Anderson 1990). In the Balkans, ever since the romantic ideas of the unification of the South Slavs in the mid nineteenth century, language was an important aspect of how people viewed themselves (White 2000). As a consequence of the events in the region in the 1990s, language developed a political aspect and became related to territory, i.e., to the 'political organisation of space'(White 2000, 181).

According to Article 9 of the 1992 Constitution, the 'language in official use' in Montenegro was the ijekavski dialect of Serbian. Prior to the disintegration of Yugoslavia, the language was termed as Serbo-Croatian/Croato-Serbian. After the break-up of the former Yugoslavia, the successor states enshrined separate languages in their constitutional frameworks, named after the state or having reference to it (Radojević 1989, 7). In the FRY, and in Montenegro, the official language remained Serbian, which has been changed after Montenegro became an independent state. The constitutional provisions related to language are a further indication of the politicisation of a cleavage, which reinforced the ethno-cultural narrative of the ruling elite.

In Article 13, the Constitution of Montenegro of 2007 stipulates that the 'official language in Montenegro is Montenegrin', while 'Serbian, Bosnian, Albanian and Croatian' are 'officially used languages'. During the constitutional debate, the denomination of language as Montenegrin faced fierce opposition by the former unionist bloc, which deemed it a political move (Antović in Pobjeda 20/6/2006). The unionist bloc supported the preservation of the name of the official language as Serbian, arguing that, in line with the 2003 population census (Monstat 2003), $59.7 \%$ of the people spoke the Serbian language, while $21.5 \%$ spoke Montenegrin.

At the same time, for the former pro-independence camp terming the language as Montenegrin gave legal guarantees to the political prevalence of their concept of identity based on historical grievances. The revival of the discourse over the Montenegrin language has been reinforced by the activities of the pro-independence cultural organisations, such as the Montenegrin PEN centre, and in the writings of the linguists Vojislav Nikčević and Borislav Jovanović. In the context of historical grievances, Jovanović $(2005,10)$ claimed that 'the Montenegrin language is still saw as linguistically deviant - as a variant, sub-variant, Montenegrism - in line with the unitary and assimilationist philological conceptions. However, despite this suppression, the Montenegrin language is not a dead language'. 
In addition to denominating the language as 'Montenegrin', in July 2009, the Ministry of Education of Montenegro adopted the new orthographic norms, according to which Montenegrin alphabet no longer has 30 graphemes, but 32 ('s and ź have been added). Montenegro is the only former Yugoslav successor state that has changed the alphabet, which is another indicator of the politicisation of language which thus became a structural cleavage. The divisiveness of language has also been manifest in the 2011 population census (Monstat 2011), whereby $39.8 \%$, of the population declared Montenegrin to be its native tongue, against 42.9 \% speakers of Serbian. Having in mind that $45 \%$ of Montenegro's population declared themselves as Montenegrin and $28.7 \%$ as Serb in 2011, and the above-presented 2003 census results on language, there is an indication that the overlap between language and ethnic/national identity is still fluid. However, the process is largely unfinished, which points to the fact that the linguistic cleavage displays its ethno-cultural nature once politicised and adjoined to other structural cleavages.

\section{Structuration and the typology of cleavages}

In unconsolidated political contexts cleavages are particularly susceptible to manipulation by political actors. At the time of the divide over statehood and identity, Montenegrin political elites revived ethno-cultural narratives ${ }^{\mathrm{vi}}$ and triggered the dominance of structural cleavages over the functional ones. In fact, in the late 1990s Montenegro was a society that was recovering from the effects of a negative transition, triggered by instability that followed the disintegration of Yugoslavia (Popović 2002). As a consequence of a series of political processes, Montenegro's political scene became highly polarised as of 1997, and elite competition for power became salient. Given the dynamics of elite competition, and the change in the structure of opportunities and constraints generated by Milošević's departure from power, the politicization of cleavages became imminent in attracting the electorate to the two camps. Montenegrin society had historically suffered from previous divides (e.g. religious, tribal, class, ethnic), and having left enough historical uncertainty as to the lines of this divide (Roberts 2007), they re-emerged as cleavages in the new elite competition. Consequently, old divides became politicised and transformed into ethno-cultural cleavages. As such, they became quintessential for the establishment of the identity of both the leadership and the supporters of the pro-independence/pro-Montenegrin and unionist/proSerb camps.

The overlapping cleavages that marked Montenegro's divide over statehood and identity helped the cementing of the ideas of ethno-cultural particularity of Serbs and Montenegrins to the unionist and the pro-independence camps, respectively. That is, the more overlapping cleavages were revived, the more was it possible to coagulate them around one political representation of identity. Thus, the fact that the two competing camps associated religion, with ethnic and tribal belonging, meant that the political competition occurred between two players and that these cleavages did not allow for the emergence of further competitors for power. In the case of Montenegro, this is illustrated by those people who felt Montenegrin, associated with the idea of independence, neo-Montenegrin tribes, and the CPC; and by those people who felt Serb, associated with the idea of the preservation of the common state, proSerbian tribes, and the SPC. Hence, the divide between the two camps in Montenegro cut deep into society, because overlapping cleavages tend to reinforce the perceptions of identity.

Yet, the overlapping cleavages were necessary to crystallize the difference between the two camps, largely because many of the pre-existing cleavages were cross-cutting. That is, a very similar language, or the same religion could be associated to more than one identity camp. The actual difference between the Serb and the Montenegrin language, particular prior to the standardisation of the latter in 2009, was merely denominative. Equally, whether an individual would affiliate with the SPC or the CPC was a matter of political, rather than a 
religious choice. Hence, in cases of cross-cutting cleavages, people's perception of their own identity will malleable in that it is likely that it will be associated with their political or economic interests. In such cases, the activities of political elites have a pivotal role in determining individuals' ascription to identity camps by reinforcing the cross-cutting cleavage by an overlapping one. In the case of Montenegro, this explains the cases of those people who felt Montenegrin and voted for independence, but associated with SPC and spoke Serbian; or to those people, for example, who felt Serbian, associated with SPC and spoke Serbian, but voted for Montenegrin independence. Hence, in Montenegro, the overlapping cleavages dominated over the cross-cutting ones as the determinant of the individuals' political choice.

\section{Conclusion}

Studying political parties and political systems of different countries in the world assumes an awareness of those moments in history in which social conflicts were frozen and transferred onto the political plane. The role of political elites in freezing conflicts and thus in establishing, changing, or perpetuating cleavages has only recently become a prominent research topic among political scientists (Enyedi 2005; Deegan-Krausse 2006; Chhibber and Torcal 1997), and this is largely due to the rise of new democracies in Europe. Looking at how political parties emerged in the post-communist world, Zielinski (2002: 185) noted that the degree of the politicization of cleavages is largely dependent on the activities of political elites, who may opt for instituting a particular type of cleavage as the core of political competition.

Against this background, this paper contextualised and analysed the multifaceted and complex factors that have given rise to cleavages in the recent contest over statehood and identity in Montenegro. It argued that in polities in transition, in which the processes of state and nation building are unfinished or unconsolidated, cleavages related to ethnic identity become salient in political competition. As such, cleavages become axes around which the political parties, which usually represent different ethno-cultural groups, compete for power. Moreover, looking in more detail at the case of Montenegro, this paper also showed that memories of historical divisions, particular those related to structural cleavages (religion, language, culture), are recreated as catalyst of modern political struggles.

First, the study identified the critical junctures in the divide over statehood and identity in Montenegro, thus looking at those moments in recent history in which conflict was frozen and transformed into cleavages. The paper looked at four crucial moments, and maintained that the 1989 'anti-bureaucratic' revolutions and the 2000 fall of Milošević gave rise to structural (ethno-cultural) cleavages, while the 1997 split of the DPS and 2006 Montenegro's independence generated predominantly functional (class, operational) cleavages. The paper also outlined the difference in the nature and intensity of the cleavages that emerged at different points in Montenegro's transition, and in the context of the division over statehood and identity particular attention was paid to the post-1997 cleavages. In fact, the crack within the DPS in 1997 initiated a series of political struggles that progressively resulted in the establishment of two political blocs by 2006: pro-independence and pro-union. However, as no society functions as an isolated system, the shaping of people's identity and the divide into pro-independence Montenegrins and unionist Serbs that followed was a product of a larger process. This process entailed the interaction among elites, society and exogenous influences, such as the fall Milošević in 2000, which triggered the reinvention of 
agendas of political elites and prompted the rise of further ethno-cultural cleavages. The cumulative effect of the various cleavages helped the transition of Đukanović's camp from anti-Milošević to pro-independence and of the opposition camp from pro-Milošević to unionist. Montenegrin and Serbian identities, respectively, became cemented into these two camps.

Second, the paper looked at the different ethno-cultural narratives that were used to underpin the emergence of structural cleavages and their prevalence over functional ones. This susceptibility of cleavages to political agency was gained prominence after the demise of the regime in Belgrade, when the focus of the elite competition shifted towards the debate over statehood and identity. In that respect, past events provided enough reference for the Montenegrin leadership to find examples of historical justification for their claims related to either: a) independent Montenegrin statehood and separate Montenegrin identity; or to b) the unification with Serbia and the indistinctiveness between Serbs and Montenegrins. The fact that the two competing camps selectively endorsed these narratives reinforced their arguments and made their claims 'difficult to challenge, even to disbelieve' (Sinfield 1992: 33).

This transfer of historical memory has particular significance for societies undergoing a process of transformation after the fall of the socialist rule. Old stories needed to be revived to justify social change. The memory of the previous (living) generations dated back largely to the period of the socialist rule. Thus, historical narratives of the dynastic rule, heroism and glory gained salience in shaping people's identity because they transcended the period remembered by the (living) generations. The competing elites in Montenegro placed emphasis on these stories through their discourse, use of symbols, and erection of monuments. In the polarised environment, two competing pervasive streams of collective memory were revived in order to increase the appeal of the claims of the competing camps. The difference between these streams was not merely the selection of facts surrounding historical events. Rather, it was the interpretation of the facts that was used to justify the contemporary political claims.

The study concludes by arguing that different types of cleavage had different types of impact on the political competition in Montenegro. Using Montenegro as a case-study, this research noted that the number of identity camps depends on the type of cleavages (independent, overlapping, cross-cutting) in the polity. The more independent (unrelated to other cleavages) cleavages there are, the more identity camps will gain salience in the struggle for power; the more overlapping cleavages there are, the more likely they will coagulate around one political representation of identity. Yet, if the cleavages are crosscutting (that is - cutting across several groups), then people's perception of their own identity will be malleable. In such cases, the activities of political elites have a pivotal role in determining individuals' ascription to identity camps, as indicated in the case of Montenegro. 


\section{Bibliography}

Andrijašević, Živko. Nacija s greškom. Cetinje: Đurđe Crnojević, 2004.

Bartolini, Stefano. Restructuring Europe. Centre formation, system building and political structuring between the nation-state and the European Union. Oxford: Oxford University Press, 2005.

Bieber, Florian. 'Montenegrin politics since the disintegration of Yugoslavia.' In Montenegro in Transition: Problems of Identity and Statehood, ed. by Florian Bieber, 11-42. Baden-Baden: Nomos Verlagsgesellschaft, 2003. Print.

Boehm, Christopher. Montenegrin Social Organization and Values: Political Ethnography of a Refugee Area Tribal Adaptation. New York: AMS Press, 1983.

Bulatović, Momir. Pravila ćutanja. Niš: Zograf, 2005.

Calhoun, Craig. 'Nationalism and Ethnicity.' American Review of Sociology 19 (1993): 211239. Print.

Centar za Demokratsku Tranziciju. Official results: Parliamentary Elections, 22 April 2001. Web. At: http://www.cdtmn.org/dokumenti/zvanicni-rezultati-parlamentarni-izbori2001.pdf [accessed: 25 July 2011].

----. Official results: Parliamentary Elections, 20 October 2002. Web. At: http://www.cdtmn.org/dokumenti/zvanicni-rezultati-parlamentarni-izbori-2002.pdf [accessed: 25 June 2011].

----. Referendum 21/05/2006 (23 May 2006). Web. At: http://www.cdtmn.org/izbori/referendum06.php [accessed: 20 June 2011].

Chhibber, Pradeep and Mariano Torcal, 'Elite Strategy, Social Cleavages, and Party Systems in a New Democracy’. Comparative Political Studies 30/1 (1997): 27-54. Print.

Darmanović, Srđan. 'Montenegro: Destiny of a Satellite State'. Eastern European Reporter 27 (1992):27-29. Print.

Deegan-Krause, Kevin. 'New Dimensions of Political Cleavage’. In R. J. Dalton \& H.-D. Klingemann (Eds.), Oxford Handbook of Political Behaviour. Oxford: Oxford University Press, 2007.

Douglas, Mary. Implicit Meanings. London: Penguin, 1975.

Đurković, Miša. 'Montenegro: Headed for New Divisions'. Conflict Studies Research Centre 07/09 (Swindon: Defence Academy of the United Kingdom, March 2007): 1-14. Print.

Enyedi, Zsolt. Party politics in post-communist transition. In R. S. Katz \& W. Crotty (Eds.), Handbook of Party Politics. London: Sage, 2006.

Federal Statistical Office. Population Census 1981, 1991. Belgrade: FZS, 1992.

International Crisis Group. 'Montenegro: In the Shadow of the Volcano.' Balkans report No. 89 (21 March 2000).

Jovanović, Jagoš. Istorija Crne Gore. Cetinje: Izdavacki Centar, 1995.

Krastev, Ivan and Alina Mungiu-Pippidi (eds.). Nationalism after Communism. Budapest: CEU Press, 2004. 
Kubo, Keiichi. 'The issue of Independence and Ethnic Identity in Montenegro.' Southeastern Europe 31-32 (2004/2005): 163-180.

Lipset, Seymour and Stein Rokkan. Party Systems and Voter Alignments. New York-London: The Free Press-Collier-Macmillan, 1967.

Mair, Peter. 'The freezing hypothesis. An evaluation'. In L. Karvonen \& S. Kuhnle (Eds.), Party Systems and Voter Alignments Revisited, pp. 27-44. London and New York: Routledge, 2001.

Martin, Pierre. Comprendre les évolutions électorales. La théorie des réalignements revisitée. Paris: Presses de Sciences Po, 2000.

Morrison, Kenneth. Montenegro: A Modern History. London: IB Taurus \& Co., 2009.

Pobjeda (06 January 1995). Print.

Popović, Milan. Montenegrin Mirror: Polity in Turmoil 1991-2001. Podgorica: Nansen Dijalog Centar, 2002.

Radonjić, Radovan. Tranzicije. Podgorica: CID, 1998.

Roberts, Elizabeth. Realm of the Black Mountain: A History of Montenegro. Oxford: Blackwell, 2007.

Rokkan, Stein. Citizens, Elections, Parties. Approaches to the Comparative Study of the Processes of Development. Oslo: Universitetsforlaget, 1970.

Rokkan, Stein. State Formation, Nation-Building, and Mass Politics in Europe: The Theory of Stein Rokkan, Based on His Collected Works, edited by Peter Flora with Stein Kuhnle and Derek Urwin Oxford: Oxford University Press, 1999.

Santoro, Lara.'From Baptism to Politics, Montenegrins Fight for Identity.' Christian Science Monitor 91/103 (23 April 1999): 7-9. Print.

----.'Yugoslavia’s junior partner walks fine line between Milosevic, West.' Christian Science Monitor 91/98 (16 April 1999): 7. Print.

Simić, Andrei. 'Montenegro: Beyond the Myth.' Crises in the Balkans: Views from the Participants, ed. by Constantine P. Danopoulos and Kostas Messas, 113-134. London \& Colorado: Westview Press, 1997.

Strmiska, Maximilian. 'The Making of Party Pluralism in Montenegro.' Conflict Prevention 2005. Web. At: http://www.conflict-prevention.net/search [accessed: 09 July 2011].

Sinfield, Alan. Faultlines: Cultural Materialism and the Politics of Dissident Reading. Oxford: Oxford University Press, 1992.

Šuković, Mijat. 'Srpstvo kao ideologija i politika u Crnoj Gori.’ Pobjeda (19 September 1999). Print.

Van Meurs, Wim. 'The Belgrade Agreement: Robust Mediation between Serbia and Montenegro.’ In Montenegro in Transition: Problems of Identity and Statehood, ed. by Florian Bieber, 63-82. Baden-Baden: Nomos Verlagsgesellschaft, 2003. Print.

Zavod za Statistiku Crne Gore. 2003 Population Census of Montenegro. Web. At: http://www.monstat.cg.yu/Popis.htm [accessed: 24 June 2011].

----. 2011 Population Census of Montenegro. Web. At: http://www.monstat.cg.yu/Popis.htm [accessed: 24 July 2011]. 
Zielinski, Jakub.' Translating Social Cleavages Into Party Systems: The Significance of New Democracies'. World Politics 54 (2002): 184-211. Print. 
Table 1. Polarisation of Montenegrin political life in April 2001

\begin{tabular}{|l|c|c|}
\hline \multicolumn{1}{|c|}{ Party/Coalition } & Affiliation & \% \\
\hline Liberal Alliance of Montenegro & MNE & 7.9 \\
\hline Serbian Radical Party ‘Dr Vojislav Šešelj' & YUG & 1.2 \\
\hline Liberal Democratic Party & MNE & 0.1 \\
\hline Party of Democratic Prosperity - Osman Redža & MNE & 0.4 \\
\hline Democratic Alliance of Montenegro & MNE & 1.0 \\
\hline Bosniak-Muslim Coalition in Montenegro & MNE & 1.1 \\
\hline $\begin{array}{l}\text { Party protecting the savings and social security of } \\
\text { citizens }\end{array}$ & N/A & 0.05 \\
\hline Together for Yugoslavia & YUG & 40.8 \\
\hline $\begin{array}{l}\text { People's Unity for Montenegro - Dr Novak } \\
\text { Kilibarda }\end{array}$ & MNE & 0.1 \\
\hline Democratic Union of Albanians & MNE & 1.2 \\
\hline Yugoslav left in Montenegro & YUG & 0.05 \\
\hline Party protecting the savings in foreign currency & N/A & 0.2 \\
\hline 'Victory is Montenegro' - Milo Đukanović & MNE & 42.4 \\
\hline $\begin{array}{l}\text { Communist and Workers' Parties - for Yugoslavia } \\
\text { and self-management }\end{array}$ & YUG & 0.5 \\
\hline Party of the Law of Nature & N/A & 0.1 \\
\hline People’s Socialist Party - Momir Bulatović & YUG & 2.9 \\
\hline \multicolumn{2}{|c|}{ Summary } \\
\hline
\end{tabular}


Table 2. Polarisation of Montenegrin political life in May $1998^{\text {viii }}$

\begin{tabular}{|l|c|c|}
\hline \multicolumn{1}{|c|}{ Party/Coalition } & Affiliation & \% \\
\hline Liberal Alliance of Montenegro & AM & 6.3 \\
\hline Serbian Radical Party 'Dr Vojislav Šešelj' & PM & 1.2 \\
\hline For Serbdom & PM & 0.4 \\
\hline Serbian People's Radical Party in Montenegro & PM & 0.2 \\
\hline Yugoslav United Left in Montenegro & PM & 0.1 \\
\hline Democratic Alliance in Montenegro & AM & 1.6 \\
\hline Bosniak-Muslim List in Montenegro & AM & 0.1 \\
\hline Party of the Law of Nature & N/A & 0.2 \\
\hline Socialist People's Party - Momir Bulatović & PM & 36.1 \\
\hline Serbian People's Party & PM & 1.9 \\
\hline Party protecting the savings in foreign currency & N/A & 0.1 \\
\hline League of Communists of Yugoslavia - Communists & PM & 0.5 \\
of Montenegro & & \\
\hline 'For a Better Life' - Milo Đukanović & AM & 49.5 \\
\hline Party of Citizens having savings in foreign currency & N/A & 0.1 \\
\hline Party of Democratic Action in Montenegro & AM & 0.6 \\
\hline Democratic Union of Albanians & AM & 1.0 \\
\hline Party of Human Ways & N/A & 0.1 \\
\hline \multicolumn{2}{|c|}{ Summary } \\
\hline
\end{tabular}




\section{Endnotes}

\footnotetext{
${ }^{\mathrm{i}}$ All factions are rounded to the first decimal.

${ }^{i i}$ Negative transition: stability to instability

iii See section 2.2.

${ }^{\text {iv }}$ The 1999 Kosovo war did not feature as a critical juncture in Montenegro, because it did not cause any major political shifts. Rather, the handling of the Kosovo war by Đukanović's camp was a part of the policy of creeping independence'. For the pro-Milošević camp, the conflict reaffirmed the existing political beliefs based on the close links with Serbia.

${ }^{v}$ Identity in Slovenia articulated itself through both linguistic and religious particularities; the one in Croatia had religion as a clear marker of identity from the identities with which it shared the same language; the one in Macedonia had language to differentiate it from identities with which it shared the same religion; and the case of the three conflicting identities in Bosnia and Herzegovina proved the importance of the religious cleavage in the process of identity reconstruction after the break-up of Yugoslavia.

${ }^{v i}$ Party cleavages that existed in Montenegro's history did not reproduce themselves during the divide (see Morrison 2009). Rather, the narrative of the divide between Greens and Whites, opposing and supporting the unconditional unification of Montenegro with Serbia in 1918, became entrenched in the narratives that helped to establish the identities of the pro-independence and unionist camps.

vii Table constructed in line with data from: Centar za Demokratsku Tranziciju, Official results: Parliamentary Elections, 22 April 2001. Web. At: http://www.cdtmn.org/dokumenti/zvanicni-rezultati-parlamentarni-izbori2001.pdf [accessed: 25 June 2011]

viii Table constructed by this author with data from: Centar za Demokratsku Tranziciju, Official results: Parliamentary Elections, 31 May 1998. Web. At: http://www.cdtmn.org/dokumenti/zvanicni-rezultatiparlamentarni-izbori-1998.pdf [accessed: 25 June 2011]
} 